Int. J. Morphol.,

32(1):275-278, 2014.

\title{
Inca Bone in Human Skulls of the West Anatolian Population
}

\author{
Hueso Interparietal en Cráneos Humanos de la Población de Anatolia Occidental
}

\author{
Sibel Cirpan*; Funda Aksu* \& Nuket Mas*
}

CIRPAN, S.; AKSU, F. \& MAS, N. Inca bone in human skulls of the west Anatolian population. Int. J. Morphol., 32(1):275-278, 2014.

SUMMARY: The Inca bones are rarely seen among other inter sutural bones and are accepted as variants of the normal. The incidence of the Inca bones has been researched in different populations. The aim of this study was to investigate the rate and types of the Inca bones in West Anatolian population. One hundred fifty-one skulls of West Anatolian subjects of unknown ages and sex were examined. None of the specimens showed signs of prior cranial surgery, bony malformation or trauma. The skulls were classified as adults with teeth eruption. The Inca bones were macroscopically determined and analysed. The samples were photoghraphed with Canon $400 \mathrm{~B}$ (55 mm objective). We follow previous criteria and nomenclatures of the Inca bones. The incidence of Inca bones of examined skulls was 1.98\% (3/ 151). We observed 1 incomplete lateral asymmetric, 1 complete undivided and 1 complete asymmetric bipartita Inca bones. Inca ossicles are accessory bones found in human skulls due to ossification failure. Inca bones can be used in personal identification by comparing the ante- and post-mortem radiographs. There are some regional variations in frequencies within each restricted geographical area. In the present study, the incidence of the Inca bones is $1.98 \%$ in West Anatolian population. The frequency of the Inca bones in the skulls belonging to Hellenistic Roman periods of Cyprus and Constantinople in Natural History Museum of Turkey was $1.59 \%$. The variation in Anatolia's population at different times and regions, because of the migrations, may cause the differences between frequencies in these studies. Evaluation of the presence of the Inca bones may be usefull in identification in forensic medicine and paleodermographical studies.

KEY WORDS: Neurocranium; Sutural bones; Inca bones; West Anatolia.

\section{INTRODUCTION}

The neurocranium in adult is formed by four singular bones (frontal, ethmoidal, sphenoidal and occipital bones) centered on the midline. Two pairs of temporal and parietal bones are located bilaterally on each side of the cranium. The bones of the calvaria are formed by intramembranous ossification of head mesenchyme from the neural crest (Moore \& Dalley, 2006).

Cranial variations in the developmental period cause one or more isolated bones in the upper squamo of the occipital bone that are called as Inca bones (Bellamy, 1964; Rivero \& Tschudi, 1854). Inca bones are less frequent than the other inter sutural bones such as Wormian bones (Marathe et al., 2010).

The portion of the occipital squamo superior to the nuchal line shows membranous ossification, but the portion below the nuchal line shows cartilagineous ossification (Matsumura et al., 1993, 1994). In the membranous part, there are 3 pairs of ossification centers, one of them appears on each side of the midline between the superior and highest nuchal lines, two of them are found on each side above the highest nuchal line (Matsumura et al., 1993, 1994; Niida et al., 1992; Srivastava, 1992; Zawisch, 1957). The defect in the fusion of these ossifying nuclei causes the formation of Inca bones (Bellamy; Rivero \& Tschudi).

The number and shape of the bones change according to the place of the fusion failure occurred among these ossifying nuclei (Srivastava). Inca bones are surrounded by lambdoid and mendosal sutures (Williams et al., 1995). Longitudinal sutures rarely divide the Inca bones resulting in bipartite, tripartite or multipartite bones (Hauser \& De Stefano, 1989).

These Inca bones are accepted as variants of the normal (Marathe et al.). Gordon (1963) reported that Inca bone resembles a triangular architectural monument design of the Inca tribe.

\footnotetext{
* Department of Anatomy, Faculty of Medicine, Dokuz Eylül University, Inciralti, Izmir, Turkey.
} 
Inca bones may be misdiagnosed as a fracture line on roentgenographs (Marathe et al.). The presence of Inca osssicles may be beneficial for personal identification in both forensic medicine (if ante-mortem $\mathrm{x}$-ray radiograph is available) and antropology (Shiono et al., 1983; Purkait \& Chandra, 1989).

Inca bones and other neurocranial variables have been reported throughout the world (Carolineberry \& Berry, 1967; Nayak \& Soumya, 2008); furthermore, the incidence of the Inca bones has been researched in different populations (Hanihara \& Ishida, 2001). The geographical conditions affects the frequency of Inca bones (Hanihara \& Ishida; Martin \& Saller, 1959). Deol \& Truslove (1957) studied the formation of the Inca bones in mice and they concluded that it was genetically controlled. Torgersen (1951) reported that the Inca bone is inherited as a dominant trait with $50 \%$ penetrance.

The aim of this study was to investigate the rate and types of the Inca bones in skulls of West Anatolian population.

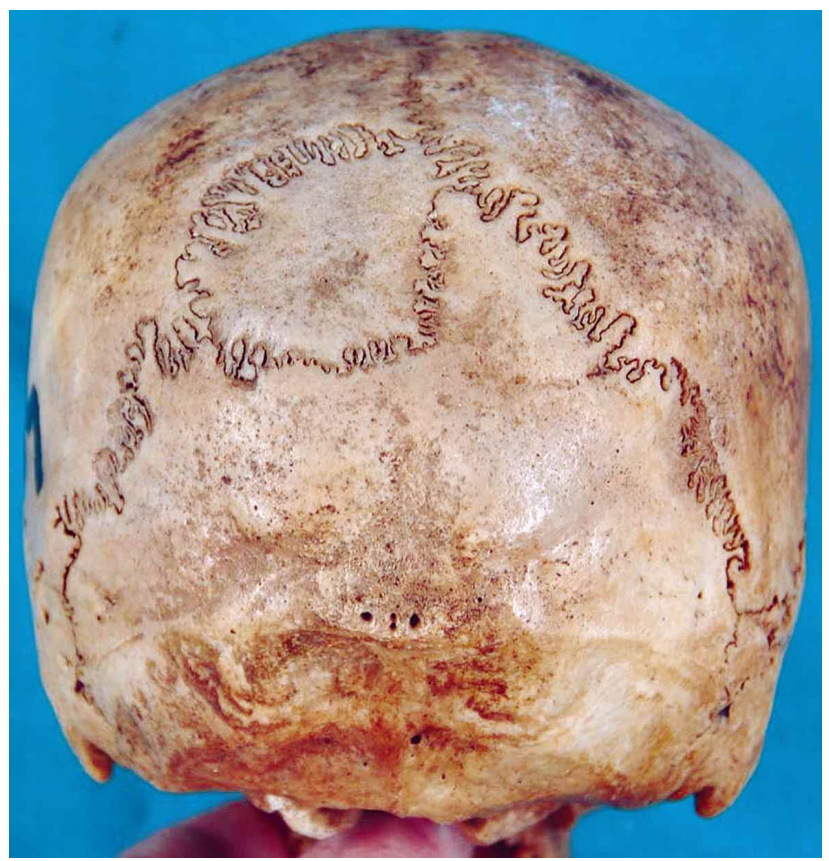

Fig. 1. Incomplete lateral asymmetric Inca bone in West Anatolian skull.

Table I. Types and frequencies of the Inca bones.

\begin{tabular}{lcc}
\hline & $\mathbf{n}$ & $\mathbf{\%}$ \\
\hline Inca bones & $3(151)$ & 1.98 \\
Incomplete lateral asymmetric type & $1(3)$ & 33.33 \\
Complete undivided type & $1(3)$ & 33.33 \\
Complete asymmetric bipartita type & $1(3)$ & 33.33 \\
\hline
\end{tabular}

\section{MATERIAL AND METHOD}

One hundred fifty-one skulls of West Anatolian people of unknown ages and sex belonging to the Anatomy Department Laboratory of Dokuz Eylul University Medical School were examined in 2012. None of the specimens showed signs of the prior cranial surgery, bony malformation or trauma. The skulls were classified as adults with the eruption of the teeth. The Inca bones were macroscopically determined and analysed. All evaluations were performed by two examiners blinded to results of each other's evaluations. The samples were photoghraphed with Canon 400B (55 mm objective). In the present study, we follow Hauser \& De Stefano and Kadanoff \& Mutafov (1968) for criteria and nomenclatures of the Inca bones. Official permission was obtained from Dokuz Eylul University Medical School. The collected data was analysed statistically.

\section{RESULTS}

The incidence of Inca bones of examined skulls was $1.98 \%$ (3/151). We observed one incomplete lateral asymmetric (Fig. 1), one complete undivided (Fig. 2) and one complete asymmetric bipartita (Fig. 3) Inca bones. In the present study, we didn't find any complete tripartite or multipartite Inca bones. Types and frequencies of the Inca bones were displayed in Table I.

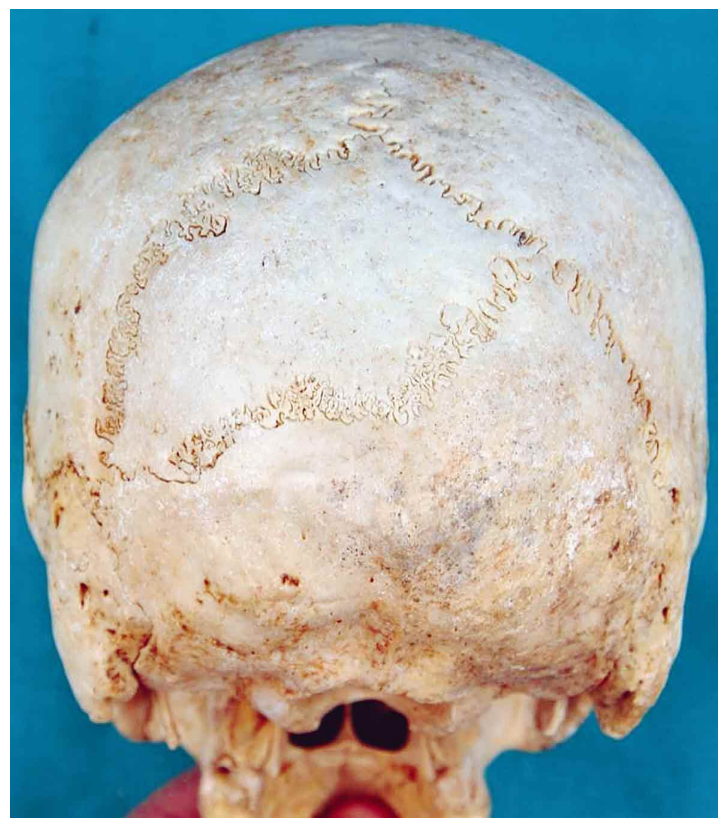

Fig. 2. Complete undivided Inca bone in West Anatolian skull. 


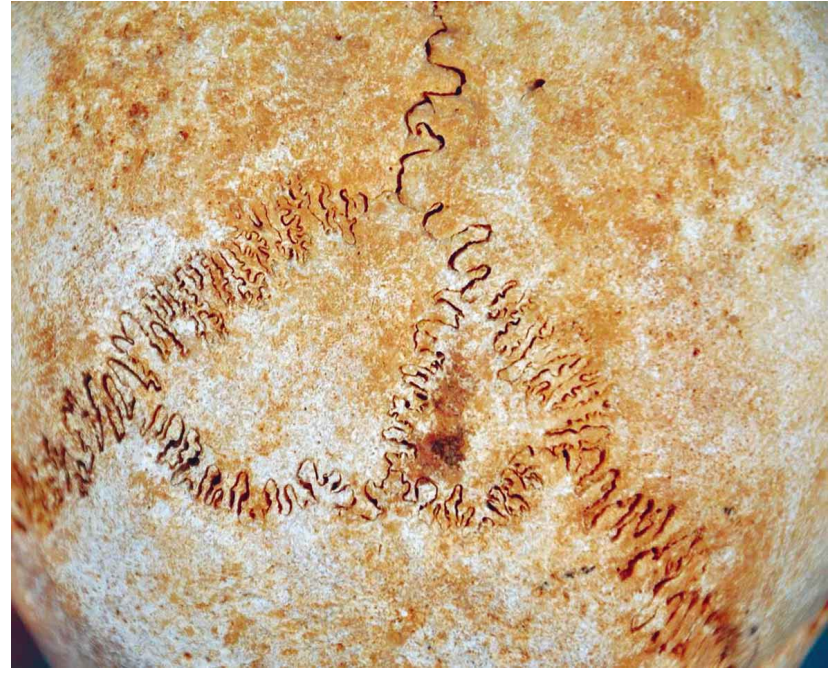

Fig. 3. Complete asymmetric bipartita Inca bones in West Anatolian skull.

\section{DISCUSSION}

Inca ossicles are accessory bones found in human skulls due to ossification failure. In the intrauterine life, the fetal skulls show the ossification center aproximately $2^{\text {nd }}$ and $3^{\text {rd }}$ months of gestation (Ranke, 1898).

Fujita et al. (2002), reported two forensic cases that had a complete tripartite and complete asymmetric bipartite bones in the interparietal region of each occipital bones in autopsy and in the ante-mortem cranial radiographs; they concluded that Inca bones can be used in personal identification by comparing the ante- and post-mortem radiographs. Shiono et al., also reported a case of Inca bone that was found incidentally in skeletonised human remains.

Inca bones can also be misdiagnosed as a fracture on the cranium. Hanihara \& Ishida examined the geographical and ethnographical patterns of the freguency variation of the Inca bone in major human populations around the world. They found that the effect of geographical conditions in occurrence of Inca bone was not clear, whereas there were some regional variation in frequencies within each restricted geographical area. Inca bones were rarely observed in Western Eurasian and Northest Asian samples. Northest Coast of the New World and West African population showed relatively high frequencies of Inca bones.

Marathe et al., examined 380 adult human skulls in India, and they found that the incidence of the Inca bones was $1.31 \%$ (5/380) and two of 5 Inca bones were fragmented.
Shapiro \& Robinson (1976) reported that a single large triangular bone (complete undivided) was the most common type of Inca bones. In the present study, the incidence of the Inca bones is $1.98 \%$ in West Anatolian population and is more than India. There is only 1 fragmented Inca bone. Hanihara \& Ishida (2001) examined the skulls belonging to Hellenistic Roman periods of Cyprus and Constantinople in Natural History Museum of Turkey. The frequency distribution of the Inca bones in Turkey was found as 1.59\%, and it is less than the present study (1.98\%). The variation in Anatolia's population in different times and regions, because of the migrations, may cause the differences between frequencies in these studies.

Evaluation of the presence of the Inca bones may be usefull in identification in forensic medicine and paleodermographical studies.

CIRPAN, S.; AKSU, F. \& MAS, N. Hueso Interparietal en Cráneos Humanos de la Población de Anatolia Occidental. Int. J. Morphol., 32(1):275-278, 2014.

RESUMEN: Los huesos interparietales no son frecuentes entre otros huesos suturales interrelacionados y se reconocen como variantes de la normalidad. La incidencia de los huesos interparietales ha sido investigada en diferentes poblaciones. El objetivo de este estudio fue investigar el índice y tipo de hueso interparietal en la población de Anatolia Occidental. Fueron examinados 151 cráneos de individuos de Anatolia Occidental de edades y sexo desconocido. En las muestras no se observaron signos de cirugía craneal previa, malformación ósea o trauma. Los cráneos fueron clasificados como adultos con erupción dental. Los huesos interparietales fueron clasificados y analizados macroscópicamente y se realizaron fotografías de las muestras con equipo Canon 400B (objetivo de $55 \mathrm{~mm}$ ). Se utilizó la norma para los criterios y nomenclatura de los huesos interparietales. La incidencia de los huesos interparietales en los cráneos examinados fue de 1,98\% (3/151). Se registró una asimetría incompleta lateral, una sin división y una asimétrica bipartita total en los huesos examinados. Los huesos interparietales se utilizan en la identificación de individuos mediante la comparación de radiografías ante-mortem y post-mortem. Existen algunas variaciones de región en las frecuencias dentro de cada área de posición limitada. En el presente estudio la incidencia de los huesos interparietales es de 1,98\% en la población de Anatolia Occidental. En el Museo de Historia Natural de Turquía, el índicede huesos interparietales en cráneos pertenecientes a los períodos romano helenístico de Chipre y Constantinopla fue de 1,59\%. La variación en la población de Anatolia en diferentes épocas y regiones debido a las migraciones, puede ser el motivo de las diferencias en las investigaciones. La evaluación de la presencia de huesos interparietales puede ser útil para la identificación en la medicina forense y estudios paleodemográficos.

PALABRAS CLAVE: Neurocraneo; Hueso sutural; Hueso intraparietal; Anatolia Occidental. 


\section{REFERENCES}

Bellamy, C. F. Cited in Kadanoff, D. \& Mutafov, S. Os incae bei Bulgaren. Morphol. Jahrb., 105:602-15, 1964.

Carolineberry, A. \& Berry, R. J. Epigenetic variation in the human cranium. J. Anat., 101(Pt. 2):361-79, 1967.

Deol, M. S. \& Truslove, G. M. Genetical studies on the skeleton of the mouse. XX Maternal physiology and variation in the skeleton of C57BL mice. J. Genetics, 55(2):288-312, 1957.

Fujita, M. Q.; Taniguchi, M.; Zhu, B. L.; Quan, L.; Ishida, K.; Oritani, S.; Kano, T.; Kamikodai, Y. \& Maeda, H. Brief communication, Inca bone in forensic autopsy: a report of two cases with a review of the literature. Leg. Med. (Tokyo), 4(3):197-201, 2002.

Gordon, S. The Book of knowledge. $6^{\text {th }}$ ed. London, Waverlay Book Co. Ltd., 1963. pp.161-6.

Hanihara, T. \& Ishida, H. Os Incae: Variation in frequency in major human population groups. J. Anat., 198(Pt. 2):137-52, 2001.

Hauser, G. \& De Stefano, G.F. Epigenetic variants of the human skull. Stuttgart, E. Schweizerbart, 1989.

Kadanoff, D. \& Mutafov, S. T. Uber die Variationen der typisch lokalisierten uberzahligen Knochen und Knochenfortsatze des Hirnschadels beim Menschen. Anthrop. Anz., 31:28-39, 1968.

Marathe, R.; Yogesh, A.; Pandit, S.; Joshi, M. \& Trivedi, G. Inca interparietal bones in neurocranium of human skulls in central India. J. Neurosci. Rural Pract., 1(1):14-6, 2010.

Martin, R. \& Saller, K. Lehrbuch der Anthropologie, Band II. Stuttgart, Gustav Fischer, 1959. pp.1295-358.

Matsumura, G.; Uchiumi, T.; Kida, K.; Ichikawa, R. \& Kodama, G. Developmental studies on the interparietal part of the human occipital squama. J. Anat., 182(Pt. 2):197-204, 1993.

Matsumura, G.; England, M. A.; Uchiumi, T. \& Kodama, G. The fusion of ossification centres in the cartilaginous and membranous parts of the occipital squama in human fetuses. J. Anat., 185(Pt. 2):295-300, 1994.

Moore, K. L. \& Dalley, A. F. Head. Chapter 7. In: Moore, K. L. \& Dalley, A. F. Clinically Oriented Anatomy. 5th ed. Philadelphia, Lippincot Williams \& Wilkins, 2006. p.886.

Nayak, S. \& Soumya, K. V. Unusual sutural bones at pteryon. Int. J. Anat. Var., 1:19-20, 2008.

Niida, S.; Yamasaki, A. \& Kodama, H. Interference with interparietal growth in the human skull by the tectum synoticum posterior. J. Anat., 180(Pt. 1):197-200, 1992.
Purkait, R. \& Chandra, H. The identity of Inca, medicolegal importance and suggested nomenclature of variants. J. Anat. Soc. India, 38(3):162-71, 1989.

Ranke, J. Der Stirnfortsatze der Schalafenschuppe bei den Primaten. S. Math. Phys. Cl. Ak. Wiss. Zu Mun., 27:227-70, 1898.

Rivero, M. E. \& Tschudi, J. J. Peruvian antiquities. Translated into English from the original Spanish by Hawkes, F. L. New York, George P. Putman \& Co., 1854. pp.38-9.

Shapiro, R. \& Robinson, F. The os incae. AJR Am. J. Roentgenol., 127(3):469-71, 1976.

Shiono, H.; Muraoka, S.; Adachi, H.; Tabata, N. \& Morita, M. An Os Incae in the occipital region of the cranium found during identification of skeleton. Res. Pract. Forens. Med., 26:35-9, 1983.

Srivastava, H. C. Ossification of the membranous portion of the squamous part of the occipital bone in man. J. Anat., 180(Pt. 2):219-24, 1992.

Torgersen, J. Hereditary factors in the sutural pattern of the skull. Acta Radiol., 36(5):374-82, 1951.

Williams, P. L.; Bannister, L. H.; Berry, M. M.; Collins, P.; Dyson, M. \& Dussek, J. E. Gray's Anatomy. The skull. $38^{\text {th }}$ ed. London, Churchill Livingstone, 1995. pp.583-606.

Zawisch, C. Der Ossifikationprozess des Occipitale und der Rolle des Tectum posterius beim Menschen. Acta Anat., 30:9881007, 1957.

\author{
Correspondence to: \\ Sibel Cirpan, M.D. \\ Dokuz Eylül University \\ Faculty of Medicine \\ Department of Anatomy, 35340 \\ Inciralti, Izmir \\ TURKEY
}

Email: cirpansibel@hotmail.com

Received: 19-07-2013

Accepted: 29-11-2013 